\title{
Total wrist arthrodesis with wrist fusion rod in patients with rheumatoid arthritis
}

\author{
Romatoid artritli hastalarda el bileği füzyon çubuğu ile total el bileği artrodezi
}

\author{
Kenji Onuma, MD., PhD., Ryosuke Shintani, MD, Hisako Fujimaki, MD., \\ Koji Sukegawa, MD., Tomonori Kenmoku, MD., PhD., Kentaro Uchida, PhD., \\ Naonobu Takahira, MD., PhD. Masashi Takaso, MD., PhD. \\ Department of Orthopaedic Surgery, Kitasato University School of Medicine, Kanagawa, Japan
}

\begin{abstract}
Objectives: This study aims to retrospectively review the short-term surgical outcome of wrist fusion using wrist fusion $\operatorname{rod}($ WFR).

Patients and methods: Six wrists of four female patients (mean age 56 years; range 51 to 62 years) with advanced stage rheumatoid arthritis of Larsen IV or V were performed total wrist fusion using WFR. Clinical outcome was assessed using a numeric rating scale of pain satisfaction level. Bony fusion, correction of palmar subluxation and ulnar deviation, rod bending angle, wrist fusion angle, and complications were assessed from radiographs.
\end{abstract}

Results: All wrists achieved painless wrist stability with bony fusion of the radiocarpal joint. Both the palmar subluxation and ulnar deviation were corrected in all patients. Two radiographic complications were observed: rod fracture in one patient and a radiolucent line in proximal metacarpal bone in another patient. Both complications might have occurred as a result of instability of the third carpometacarpal joint, but neither influenced clinical outcome. Wrist fusion angle was smaller than rod bending angle at final observation.

Conclusion: Wrist fusion using WFR is an option for the treatment of advanced stage rheumatoid arthritis of wrist. According to our experience, the stability of third carpometacarpal joint should be assessed before surgery, and this joint should be fused if required. The bending angle of the intramedullary rod does not directly form the wrist fusion angle in contrast to the case with a dorsal wrist fusion plate.

Keywords: Rheumatoid arthritis; total wrist fusion; wrist fusion rod.

\section{ÖZ}

Amaç: $\mathrm{Bu}$ çalışmada el bileği füzyon çubuğu (EBFÇ) kullanılan el bileği füzyonunun kısa vadeli cerrahi sonucu retrospektif olarak incelendi.

Hastalar ve yöntemler: Dört kadın hastanın (ort. yaş 56 yıl; dağılım 51-62 yıl) ileri dönem Larsen IV veya V romatoid artritli altı el bileğine EBFÇ kullanılarak total el bileği füzyonu uygulandı. Klinik sonuç, ağrı memnuniyet düzeyi sayısal değerlendirme skalası ile değerlendirildi. Kemik füzyonu, palmar subluksasyon ve ulnar deviasyonun düzelmesi, çubuk eğilme açısı, el bileği füzyonu açısı ve komplikasyonlar radyografiler ile değerlendirildi.

Bulgular: Radyokarpal eklemin kemik füzyonu ile tüm el bileklerinde ağrısız el bileği stabilitesi sağlandı. Tüm hastalarda hem palmar subluksasyon hem ulnar deviasyon düzeltildi. İki radyografik komplikasyon gözlemlendi: bir hastada çubuk kırığı ve bir başka hastada proksimal metakarpal kemikte radyolusent bir çizgi. Her iki komplikasyon üçüncü karpometakarpal eklemin instabilitesinden kaynaklanmış olabilir, fakat hiçbiri klinik sonucu etkilemedi. Son gözlemde, el bileği füzyonu açısı çubuk eğilme açısından küçüktü.

Sonuç: El Bileği Füzyon Çubuğu kullanılan el bileği füzyonu, el bileğinin ileri dönem romatoid artritinin tedavisi için bir seçenektir. Deneyimlerimize göre, üçüncü karpometakarpal eklemin stabilitesi cerrahiden önce değerlendirilmeli ve gerekirse bu ekleme füzyon yapılmalıdır. Dorsal el bileği füzyon plağı olan olgunun aksine, intramedüller çubuğun eğilme açısı doğrudan el bileği füzyonu açısını oluşturmaz.

Anahtar sözcükler: Romatoid artrit; total el bileği füzyonu; el bileği füzyon çubuğu.

- Received: January 09, 2015 Accepted: February 17, 2015

- Correspondence: Kenji Onuma, MD., PhD. 1-15-1 Kitasato, Minami-ku, Sagamihara, Kanagawa, 252-0374, Japan. Tel: 81-42-778-8111 Fax: 81-42-778-5850 e-mail: onuma@med.kitasato-u.ac.jp 
Indications for surgical treatment for the rheumatoid arthritis of wrist depend on the stage of disease. Synovectomy is preferred with the Sauve-Kapandji procedure or Darrach procedure for rheumatoid arthritis wrists without severe instability and joint distraction classified as Larsen grade II-IV ${ }^{[1]}$ and partial wrist fusion (fusion between the radius and lunate) for those classified as Larsen grade III or IV, in which the midcarpal joint remains relatively intact but the radiocarpal joint is destroyed and painful. ${ }^{[2]}$ Total wrist fusion is performed for rheumatoid arthritis wrists with severe instability and joint distraction categorized as Larsen grade IV or $V^{[3]}$ Wrist arthrodesis for these patients is a reliable procedure which provides predictable long-term pain relief and a high degree of patient satisfaction without additional functional loss in the upper limb. ${ }^{[4]}$ Although wrist fusion results in loss of motion of the wrist, patients are satisfied because the presurgical wrist is dysfunctional, with severe pain, instability, and a decreased range of motion. Total wrist fusion using a relatively new intramedullary instrument, the Wrist Fusion $\operatorname{Rod}^{\circledR}$ (WFR, Nakashima Medical, Okayama, Japan) may be performed for rheumatoid arthritis wrists. In this study, we aimed to retrospectively review the short-term surgical outcome of wrist fusion using WFR.

\section{PATIENTS AND METHODS}

Six wrists of four female patients (mean age 56 years; range 51 to 62 years) who had undergone total wrist arthrodesis with WFR at Kitasato University Hospital and Kitasato University East Hospital between January 2005 and December 2011 were retrospectively reviewed. Patient characteristics are described in Table I. Operations were performed for two right and four left wrists. Wrists were classified as Larsen grade IV or V. Mean duration of follow-up was 6.0 years (2.0 to 9.2 years). Three wrists of three patients were preoperatively complicated with rupture of the extensor tendons. All patients used a temporary wrist splint or ordinary brace before surgery for simulation. We obtained informed consent for this study from all patients.

The numeric rating scale (NRS) was used to assess pain postoperatively and at final observation (NRSP; no pain 0-10 severe pain) and level of satisfaction with surgery at final observation (NRSS; not satisfied $0-10$ very satisfied).

At the radiographic study, bone fusion of the radiocarpal and third carpometacarpal joints and radiographic complications were assessed, including carpal height, ulnar deviation and palmar subluxation of the carpus at the radiocarpal joint according to the methods of Youm et al..$^{[5]}$ Carpal height ratio and carpal ulnar distance ratio (CUDR) were measured from a posteroanterior radiograph of the wrist, and volar carpal subluxation ratio (VCSR) was measured from a lateral radiograph of the wrist preoperatively, postoperatively and at final observation.

To assess correction loss of bending angle of the rod set by the rod bender, postoperative and final rod bending angles were measured from lateral radiographs of the wrist. Percentages of angle difference ratio of the correction lag were calculated from (postoperative bending rod angle/set bending angle) x 100, and correction loss (final bending rod angle/postoperative bending angle) $\times 100$ (correction loss, except for the case of rod fracture), respectively. To assess the difference between the rod bending angle and wrist fusion angle, the wrist fusion angle was measured from lateral radiographs of the wrists and compared with the rod bending angle.

Wrist fusion was performed according to manufacturer's operative technique manual (Nakashima Medical Co., Ltd. Japan) or a text book ${ }^{[6]}$ supervised by Dr. Hajime Ishikawa, a designer of the WFR. Briefly, a dorsal oblique skin incision was made in a straight line from the middle of the third metacarpal bone to just proximal to the distal radioulnar joint. The extensor compartment was opened from the fourth compartment, and the capsule

TABLE I

Profile of patients undergoing wrist fusion with wrist fusion rod

\begin{tabular}{lcccc}
\hline Patient and operated side & Age at operation (year old) & Follow-up period (years) & Larsen grade of wrist & Tendon rupture \\
\hline 1 Right & 58 & 6 & V & VDC III to V \\
Left & 62 & 3 & V None & EDC III to V \\
2 Right & 54 & 5 & 4 & None \\
Left & 54 & 3 & IV & None \\
3 Left & 51 & 1 & IV & EDC IV and V \\
4 Left & 57 & 4
\end{tabular}

EDC: Extensor digitorum communis. 
TABLE II

Pre- and postoperative numeric rating scale for pain

\begin{tabular}{lcccc}
\hline Patient and operative wrist & Preoperative NRSP & & Postoperative NRSP & NRSS \\
\cline { 2 - 3 } & $\mathrm{n}$ & 8 & $\mathrm{n}$ & $\mathrm{n}$ \\
\hline 1 Right & 6 & 2 & 5 \\
Left & 8 & 1 & 7 \\
2 Right & 8 & 0 & 10 \\
Left & 9 & 0 & 10 \\
3 Left & 9 & 2 & 8 \\
4 Left & $8.0 \pm 1.1$ & 0 & 9 \\
Mean $\pm S E$ & $1.0 \pm 0.9$ & $8.2 \pm 1.9$ \\
\hline SE: Standard error; NRSP: No pain 0-10 severe pain, and for level of satisfaction with surgery; NRSS: Not satisfied 0-10 very satisfield.
\end{tabular}

was then opened to expose the distal radioulnar, radiocarpal, midcarpal, and third carpometacarpal (CM) joints. The ulnar head was resected at a level $25 \mathrm{~mm}$ from the tip of the ulnar head. The distal radius and proximal carpal bone were cut using a bone saw. The WFR was inserted after wire-guided drilling into the distal radius and then into the carpal and third metacarpal bone complex. The WFR was bent in situ between the radius and carpal bone with the special rod bender. Bending angle in the rod bender was set at $20^{\circ}$ or $30^{\circ}$ according to the preoperative plan. Following manual compression of the radiocarpal joint, bone chips made from resected bone were used between the radius and carpal bone. In one patient (patient 4), the defect was filled by grafting with a bone block harvested from the iliac crest. One or two staples made from $2.0 \mathrm{~mm}$ diameter titanium Kirschner wire (K-wire) were used to strengthen fixation and avoid rotation. The rod was fixed by the interlocking screw through a hole in the distal aspect of the WFR. In patient 4, the CM joint was decorticated on both sides and fixed with a staple from the proximal third metacarpal bone to the distal radius since preoperative radioscopic assessment revealed instability of the third CM joint. Bone tissue and staple were then completely covered with the capsule, floor of the compartment, and half of the transversely divided extensor retinaculum. The ulnar stump was stabilized with a flap of the pronator quadratus muscle, and the ruptured flexor tendon was restored with a side-to-side suture or bridge tendon graft harvested from the palmaris longus.

A below-elbow splint was applied for six to eight weeks after surgery. Range of motion exercises were started within a few days after surgery to avoid tendon adhesion and restore function.

\section{RESULTS}

On NRS assessment, mean pre- and postoperative NRSP were 8.0 and 1.0, respectively, and mean NRSS
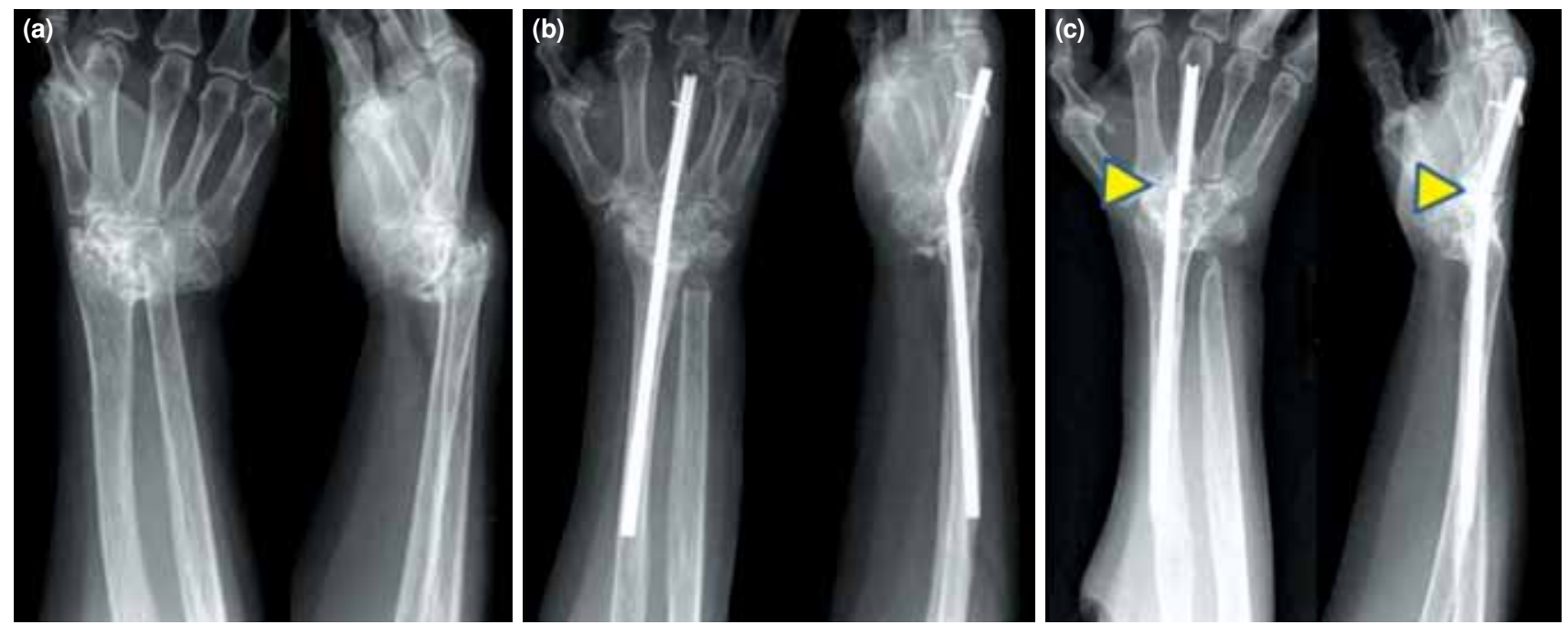

Figure 1. Wrist with rod fracture at third carpometacarpal joint (patient 1, right wrist: (a) preoperative radiograph; (b) postoperative radiograph; (c) radiograph at postoperative sixth year). 

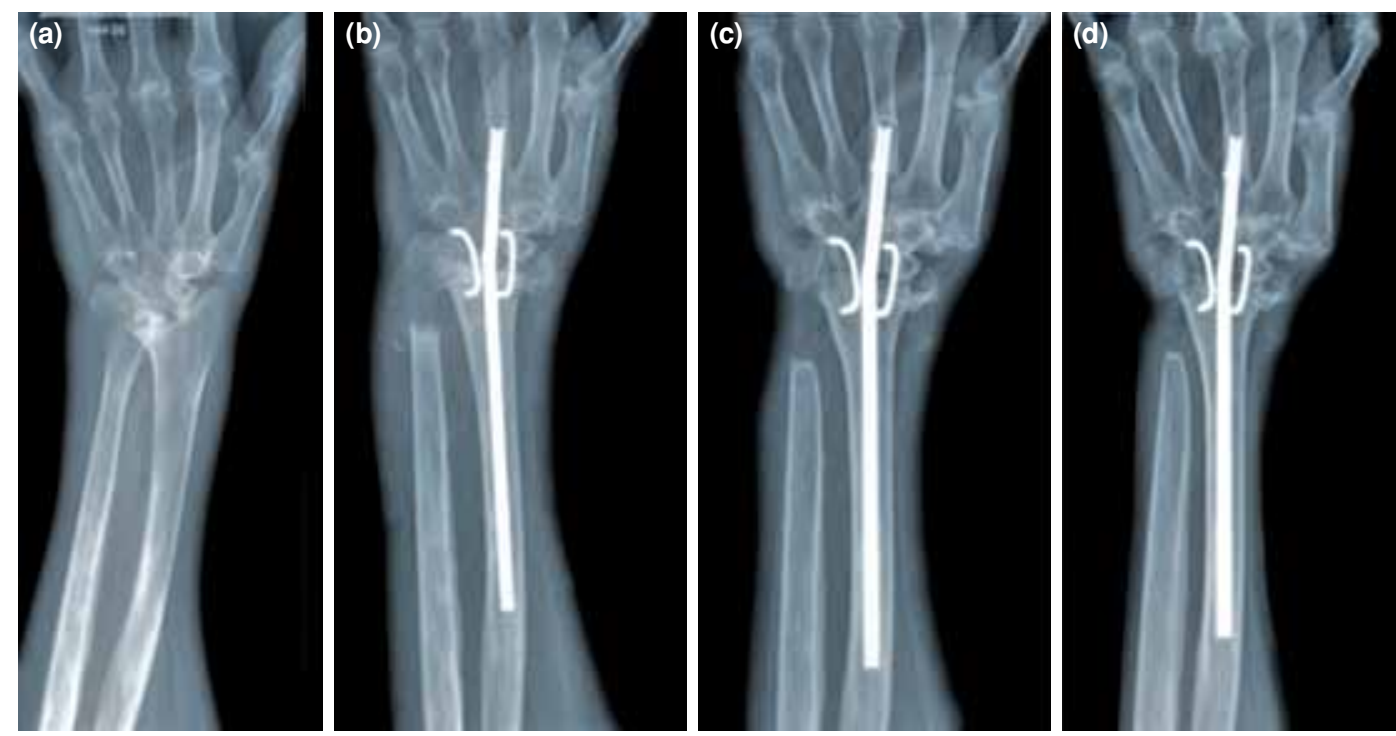

Figure 2. Wrist with radiolucent banding around proximal third metacarpal bone (patient 3 , left wrist: (a) preoperative radiograph; (b) postoperative radiograph; (c) radiograph at postoperative fourth month; (d) radiograph at postoperative third year).

was 8.2 (Table II). These results indicate that wrist fusion by this procedure significantly reduced pain and the results were satisfactory. Adhesion of tendon which led to flexion disturbance of fingers was observed in the right hand of patient 1 .

Radiographs at the last observation confirmed that fusion of the radiocarpal joint was achieved for all wrists. Rod fracture was observed in one wrist (Figure 1) and a radiolucent line which indicated osteolysis was observed in the third proximal metacarpal bone in another wrist (Figure 2,3). Both complications occurred in the wrists in which bone fusion of the carpometacarpal joint was not observed at final observation (Table III). Mean preoperative, postoperative, and final observation carpal height ratios were $0.33,0.30$, and 0.29 , respectively (Table IV); this tendency of reduction after surgery was not significant among preoperative, postoperative, and final observation ratios. Mean preoperative, postoperative and final observation CUDR were $0.23,0.03$, and 0.03 , respectively (Table IV); again this tendency to correction was not significant among preoperative, postoperative, and final observation ratios. Mean preoperative, postoperative and final observation VCSR were $0.30,0.16$, and 0.16 , respectively
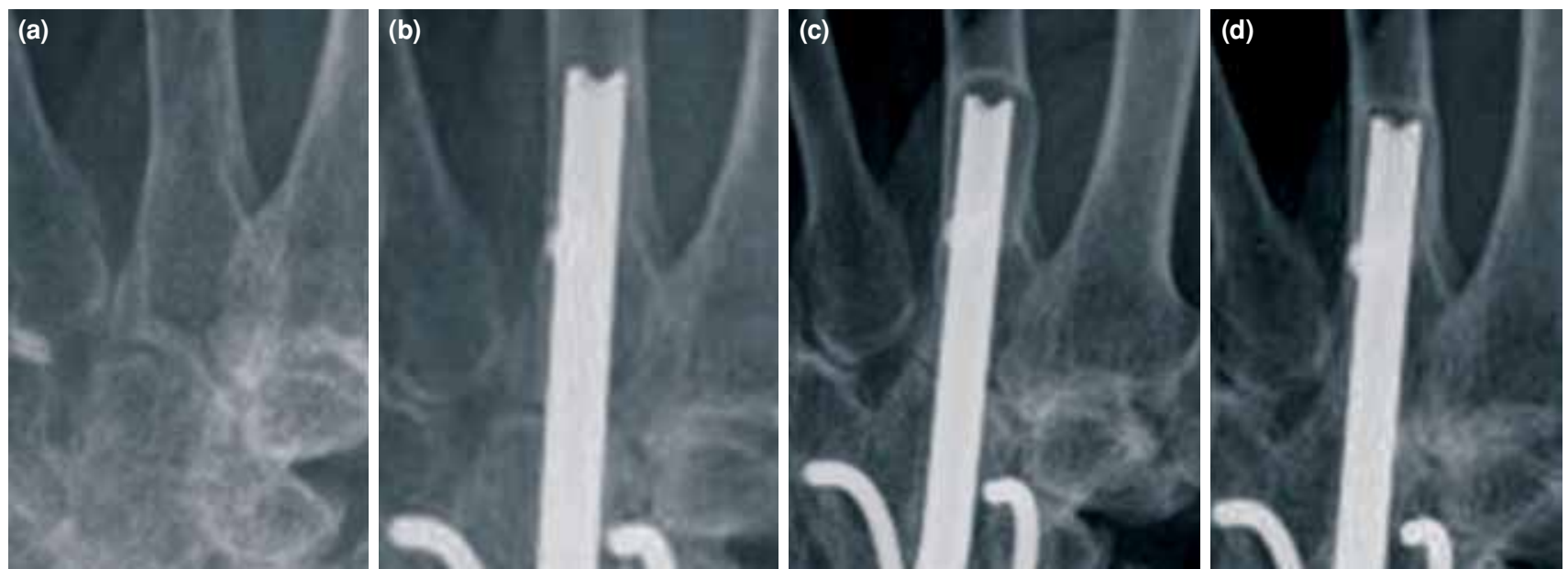

Figure 3. Magnification of Figure 2 at carpometacarpal joint [(a) preoperative radiograph; (b) postoperative radiograph; (c) radiograph at postoperative fourth month; (d) radiograph at postoperative third year)]. A radiolucent band around third metacarpal bone was observed at postoperative fourth month but it was smaller at postoperative fourth year. 
TABLE III

Preoperative and final observation radiographic assessment of third carpometacarpal joint

\begin{tabular}{lccc}
\hline Patient and operated wrist & Preoperative third CM joint & Final third CM joint & Radiographic complication \\
\hline 1 Right & Not fused & Not fused & Rod fracture \\
Left & Not fused & Fused & None \\
2 Right & Fused & Fused & None \\
Left & Fused & Fused & None \\
3 Left & Not fused & Not fused & Radiolucent band \\
4 Left & Not fused & Fused & None \\
\hline CM: Carpometacarpal. & & &
\end{tabular}

TABLE IV

Preoperative, postoperative, and final radiographic assessment and radiographic complications of six wrists

\begin{tabular}{|c|c|c|c|}
\hline \multirow{2}{*}{$\begin{array}{l}\text { Patient and } \\
\text { operated wrist }\end{array}$} & $\mathrm{CHR}$ & CUDR & VCSR \\
\hline & Pre/Post/Final & Pre/Post/Final & Pre/Post/Final \\
\hline \multirow{2}{*}{$\begin{array}{l}1 \text { Right } \\
\text { Left }\end{array}$} & $0.44 / 0.44 / 0.44$ & $0.26 / 0.00 / 0.03$ & $0.33 / 0.20 / 0.19$ \\
\hline & $0.14 / 0.14 / 0.14$ & $0.25 / 0.08 / 0.06$ & $0.35 / 0.11 / 0.12$ \\
\hline \multirow{2}{*}{$\begin{array}{l}2 \text { Right } \\
\text { Left }\end{array}$} & $0.30 / 0.26 / 0.26$ & $0.26 / 0.00 / 0.00$ & $0.13 / 0.07 / 0.07$ \\
\hline & $0.40 / 0.33 / 0.31$ & $0.14 / 0.00 / 0.00$ & $0.42 / 0.16 / 0.16$ \\
\hline 3 Left & $0.42 / 0.33 / 0.32$ & $0.17 / 0.04 / 0.03$ & $0.30 / 0.23 / 0.25$ \\
\hline 4 Left & $0.33 / 0.33 / 0.32$ & $0.27 / 0.06 / 0.06$ & $0.27 / 0.18 / 0.16$ \\
\hline Mean \pm SE & $0.33 \pm 0.11 / 0.30 \pm 0.10 * / 0.30 \pm 0.10$ & $0.23 \pm 0.06 / 0.03 \pm 0.08 N S / 0.03 \pm 0.08$ & $0.30 \pm 0.10 / 0.16 \pm 0.06 \mathrm{NS} / 0.16 \pm 0.06$ \\
\hline
\end{tabular}

CHR: Carpal height ratio; CUDR: Carpal ulnar distance ratio; VCSR: Volar carpal subluxation ratio; Pre: Preoperative; Post: Postoperative; ${ }^{*}$ p<0.05; NS: Not significant; Compared to preoperative mean value. Statistical analysis was performed by one-way ANOVA followed by Tukey's test.

(Table IV); with this difference being significant between preoperative and postoperative values, but not being significant between postoperative and final observation values. Results indicate that malalignments such as palmar subluxation and ulnar deviation of the wrist were corrected after surgery in all patients and carpal height was maintained until final observation without correction loss of carpal height. Mean angle difference ratios for assessing correction loss and correction loss were $20.0 \%$ and $-0.1 \%$, respectively (Table V). Correction lag between the set bending angle and postoperative bending angle showed no correction loss of rod bending angle and fused bone from postoperative period until final follow-up. Mean wrist fusion angle $\left(10.8^{\circ}\right)$ was significantly smaller than mean rod bending angle $\left(18.3^{\circ}\right)$ (Table VI).

\section{DISCUSSION}

Various procedures for total wrist fusion have been reported, including wrist fusion performed by bone grafting without implant; $;^{[7-9]}$ by intramedullary fixation with Rush pin (Rush Pin, LLC, Meridian, USA), Steinmann pin, or K-wire, ${ }^{[10-12]}$ and by plate

TABLE V

Bending angle set by rod bender and postoperative and final bending angle of wrist fusion rod by radiographic assessment

\begin{tabular}{|c|c|c|c|c|c|}
\hline $\begin{array}{l}\text { Patient and } \\
\text { operated wrist }\end{array}$ & $\begin{array}{c}\text { Bending angle set } \\
\text { by bender }(A)\end{array}$ & $\begin{array}{c}\text { Postoperative } \\
\text { bending angle }(\mathrm{B})\end{array}$ & $\begin{array}{l}\text { Final bending } \\
\text { angle }(C)\end{array}$ & Correction lag (\%) & Correction loss (\%) \\
\hline 1 Right & $20^{\circ}$ & $18^{\circ}$ & $17^{\circ}$ & 10 & Rod fracture \\
\hline Left & $20^{\circ}$ & $17^{\circ}$ & $18^{\circ}$ & 15 & -5.9 \\
\hline 2 Right & $30^{\circ}$ & $20^{\circ}$ & $19^{\circ}$ & 33 & 5.0 \\
\hline Left & $30^{\circ}$ & $22^{\circ}$ & $22^{\circ}$ & 26 & 0 \\
\hline 3 Left & $20^{\circ}$ & $18^{\circ}$ & $19^{\circ}$ & 10 & -5.5 \\
\hline 4 Left & $20^{\circ}$ & $15^{\circ}$ & $15^{\circ}$ & 25 & 0 \\
\hline Mean \pm SE & - & - & - & $20.0 \pm 9.7$ & $-0.1 \pm 4.9$ \\
\hline
\end{tabular}

Correction lag: (1-B/A) x 100; Correction loss: (1-C/B) x 100; SE: Standard error. 
TABLE VI

Bending angle of wrist fusion rod and wrist fusion angle by radiographic assessment

\begin{tabular}{lcc}
\hline $\begin{array}{l}\text { Patient and } \\
\text { operated side }\end{array}$ & Final bending angle & Wrist fusion angle \\
\hline 1 Right & $17^{\circ}$ & $10^{\circ}$ \\
Left & $18^{\circ}$ & $8.7^{\circ}$ \\
2 Right & $19^{\circ}$ & $9.8^{\circ}$ \\
Left & $22^{\circ}$ & $14.3^{\circ}$ \\
3 Left & $19^{\circ}$ & $16.3^{\circ}$ \\
4 Left & $15^{\circ}$ & $5.9^{\circ}$ \\
Mean $\pm S E$ & $18.3 \pm 2.3^{\circ}$ & $10.8 \pm 3.8^{\circ *}$ \\
\hline
\end{tabular}

SE: Standard error; ${ }^{*} p<0.001$ compared with final bending angle.

fixation with an $\mathrm{AO}$ dynamic compression plate, ${ }^{[13]}$ AO wrist fusion plate, ${ }^{[14]}$ and bioabsorbable rod made from self-reinforced polylevolactic acid. ${ }^{[15]}$

Although reported outcomes of wrist fusion with an $\mathrm{AO}$ dynamic compression plate and $\mathrm{AO}$ wrist fusion plate are good, synovitis and pain related to the plate have also been reported. ${ }^{[16,17]}$ Toma et al..$^{[18]}$ compared the AO plate and Mannerfelt technique in 42 rheumatoid wrists ( $\mathrm{AO}$ plate, $\mathrm{n}=23$; Mannerfelt technique, $n=19$ ), and found that although both methods relieved pain and improve function, the incidence of complications was higher in fusion with the AO plate, albeit that the difference was not significant. ${ }^{[18]}$ We therefore consider that wrist fusion is better performed using an intramedullary rod such as with the Mannerfelt technique or Millender and Nalebuff technique than with the plate techniques, which carry the risk of irritation of the extensor tendons, particularly for rheumatoid arthritis wrists, which are frequently complicated with tendon rupture.

The WFR was designed by Ishikawa and is available in Japan. Although he initially performed the Millender and Nalebuff technique with a $3 \mathrm{~mm}$ diameter K-wire as an intramedullary rod, he identified a number of problems with this technique, including migration and rotation of the K-wire, dilation of the interdigital area, risk of metacarpal bone fracture, and difficulty in obtaining an optimal wrist angle. ${ }^{[3]}$ To resolve these problems, he designed the WFR, which is a $4 \mathrm{~mm}$ or $4.5 \mathrm{~mm}$ diameter tubular titanium rod. A rod hole can be made into the medulla in advance under $1.5 \mathrm{~mm}$ diameter wire guidance to avoid fracture of the third metacarpal bone during insertion of the rod. ${ }^{[3]}$ To obtain an optimal wrist angle, the surgeon can bend the rod using a special rod bender. ${ }^{[3]}$ To avoid rotation and migration of the rod, the WFR has a fin on the proximal aspect and an interlocking screw on the distal aspect. In his series of 39 wrist fusions for rheumatoid arthritis, although bone union was achieved in 34 wrists $(87 \%)$, painless stability was achieved in all patients without major complications, and all reported satisfaction. ${ }^{[3]}$ Among other findings, pre- and postoperative mean CUDR were 0.17 and 0.07 , and mean VCSR were 0.22 and 0.14 , respectively. ${ }^{[3]}$ Rod fracture was observed in four wrists $(11 \%)$, but no migration or rotation of the rod, interdigital dilation, or fracture occurred. ${ }^{[3]}$
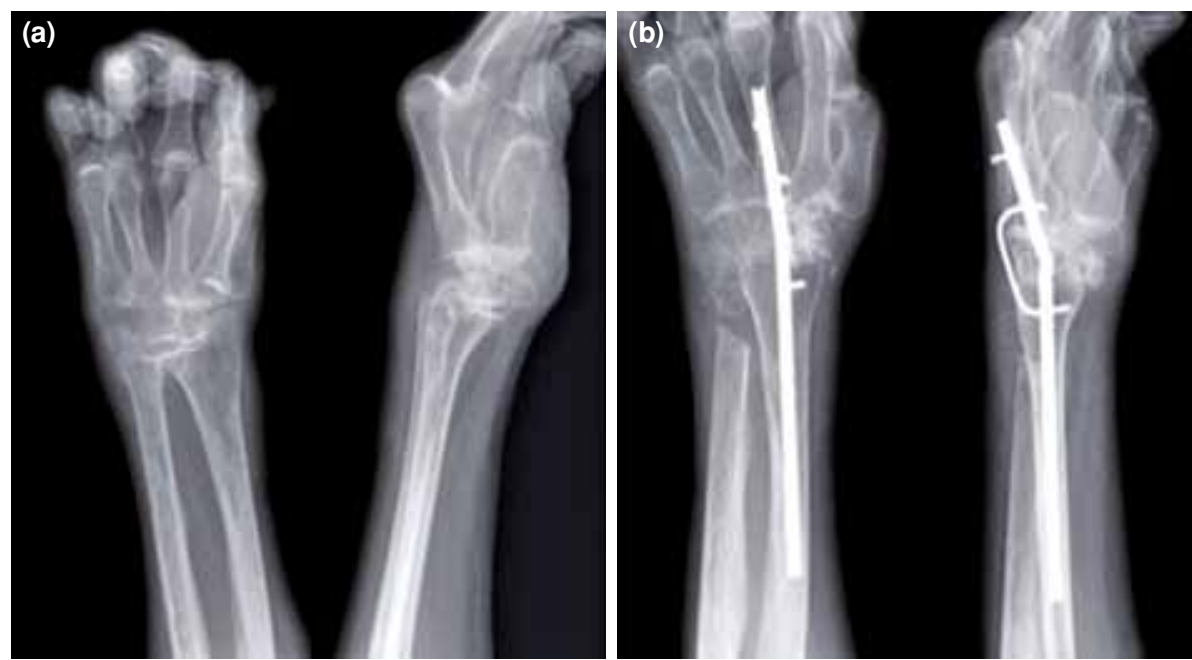

Figure 4. Left wrist radiograph of patient 4 [(a) preoperative radiograph; (b) radiograph of final (1 year) observation)]. Rod bending portion was in proximal part of third carpometacarpal joint. Distal tip of rod was slightly distal to narrowest portion of metacarpal bone. Carpometacarpal joint was fused with a staple made from a $2.0 \mathrm{~mm}$ diameter Kirschner wire stapled from proximal metacarpal bone to distal radius. 
In our study, bone union was achieved in all patients. Patients reported that pain was improved, and they were satisfied after surgery. Ulnar deviation and palmar subluxation of the carpus were corrected, as was also reported in the study of Ishikawa. Radiological review of the rod fracture showed that the bended portion of the WFR was close to the third CM joint, and that this in turn had lead to fatigue fracture of the rod due to instability of the third CM joint following wrist fusion. Furthermore, review of the radiolucent line in the third metacarpal bone showed that the WFR was inserted shallowly under the narrowest portion of the third metacarpal bone cavity, which might then have decreased rod stability and in turn caused the radiolucent band with the increased stability of the third CM joint after wrist fusion. Although the radiolucent line initially appeared as a sign of future fracture, stability of the third CM joint was fortunately observed at final observation, along with accompanying shrinkage of the radiolucent line.

In healthy individuals, the third $\mathrm{CM}$ joint is less mobile than fourth and fifth $\mathrm{CM}$ joints. In the rheumatoid arthritis wrist, in contrast, instability of the third $\mathrm{CM}$ joint is a common finding, and often follows destruction. In patient 4 (Figure 4), instability of the third $\mathrm{CM}$ joint was confirmed preoperatively using X-ray fluoroscopy. Surgery was performed with particular care to ensure that the bending portion of the WFR was not placed near the CM joint. The tip of the WFR was placed just distal to the narrowest portion of the third metacarpal bone cavity. Furthermore, the cartilage of the CM joint was resected from the base of the third metacarpal and capitate bone using a surgical burr before fusion and then fixed with a staple made from a $2.0 \mathrm{~mm}$ diameter titanium K-wire. At the final observation in this patient, the third CM joint and radiocarpal joint were shown to have achieved bony fusion and no radiographic complications due to the rod were observed. In the left wrist of patient 1 , in contrast, fusion of carpometacarpal joint was achieved without this procedure and resulted in no radiographic complications. Inclusion of the $\mathrm{CM}$ joint within the fusion mass is controversial. Abbott et al. ${ }^{[19]}$ reported that wrist fusion should not include the CM joints because of the importance of flexion and rotation at these joints during power. Urbaniak $^{[20]}$ noted that radiocarpal fusion may result in increased mobility of the $\mathrm{CM}$ joint to compensate for the wrist fusion. In contrast, Haddad and Riordan, ${ }^{[8]}$ Bolano and Green ${ }^{[21]}$ and Rauhaniemi et al. ${ }^{[22]}$ recommended that fusion of the wrist should include the third CM joints to avoid pain. In our patient with rod fracture, although she does not have wrist or $\mathrm{CM}$ joint pain in daily use, tenderness and mild instability of the third $\mathrm{CM}$ joint were observed at final follow-up. Although the reasons have not been reported, Ishikawa ${ }^{[6]}$ limits fusion of the third CM joint to those patients with instability of this joint following its destruction. Based on experiences of the patients with rod fracture and osteolysis around the proximal third metacarpal bone, we consider that it is important to assess the stability of third CM joint before each surgery and fuse it if necessary. Even if third CM joint is not destroyed, we also consider that the WFR should be inserted deeply enough in the third metacarpal bone but its bended portion should not be inserted near the third $\mathrm{CM}$ joint, as instability of $\mathrm{CM}$ joint may occur after radiocarpal fusion. We observed a correction lag between the set bending angle and postoperative bending angle. This might depend on handling of the bending or elasticity of the WSR. Further studies are required to identify the cause of correction lag. We observed a difference between the wrist fusion angle and rod bending angle at final observation. Surgeons should note that the wrist fusion angle is smaller than the rod bending angle because the bending angle of the intramedullary rod does not directly form the wrist fusion angle, in contrast to the case with a dorsal wrist fusion plate.

To our knowledge, this is the first study in the English literature describing the advantages and problems associated with wrist fusion with the WFR in patients with rheumatoid arthritis wrists. This method provides an effective and stable outcome, and we thus consider it preferable for the treatment of these patients. Preoperative assessment of the third CM joint is important in avoiding rod fracture or radiolucent line in the third metacarpal bone.

\section{Declaration of conflicting interests}

The authors declared no conflicts of interest with respect to the authorship and/or publication of this article.

\section{Funding}

The authors received no financial support for the research and/or authorship of this article.

\section{REFERENCES}

1. Kobayashi A, Futami T, Tadano I, Fujita M, Watanabe T, Moriguchi T. Radiographic comparative evaluation of the Sauve-Kapandji procedure and the Darrach procedure for rheumatoid wrist reconstruction. Mod Rheumatol 2005;15:187-90. 
2. Herren DB, Ishikawa H. Partial arthrodesis for the rheumatoid wrist. Hand Clin 2005;21:545-52.

3. Ishikawa H. Total wrist arthrodesis. Arthritis Undoukishikkan to Rinsho 2007;5:88-97.

4. Barbier O, Saels P, Rombouts JJ, Thonnard JL. Longterm functional results of wrist arthrodesis in rheumatoid arthritis. J Hand Surg Br 1999;24:27-31.

5. Youm Y, McMurthy RY, Flatt AE, Gillespie TE. Kinematics of the wrist. I. An experimental study of radial-ulnar deviation and flexion-extension. J Bone Joint Surg [Am] 1978;60:423-31.

6. Ishikawa H. Partial wrist arthrodesis and total wrist arthrodesis: Surgical reconstruction of the RA upper extremity, OS NOW Instruction No. 7. In: Kanaya F, editor. 1st ed. Tokyo: Medical View; 2008. p. 101-21.

7. Campbell CJ, Keokarn T. Total and subtotal arthrodesis of the wrist. J Bone Joint Surg [Am] 1964;46:1520-33.

8. Haddad RJ Jr, Riordan DC. Arthrodesis of the wrist. A surgical technique. J Bone Joint Surg [Am] 1967;49:950-4.

9. Carroll RE, Dick HM. Arthrodesis of the wrist for rheumatoid arthritis. J Bone Joint Surg [Am] 1971;53:1365-9.

10. Clayton ML, Ferlic DC. Arthrodesis of the arthritic wrist. Clin Orthop Relat Res 1984;187:89-93.

11. Millender LH, Nalebuff EA. Arthrodesis of the rheumatoid wrist. An evaluation of sixty patients and a description of a different surgical technique. J Bone Joint Surg [Am] 1973;55:1026-34.

12. Mannerfelt L. Osteosyntheses in rheumatoid arthritis. Handchirurgie 1976;8:29-31.
13. Wright CS, McMurtry RY. AO arthrodesis in the hand. J Hand Surg [Am] 1983;8:932-5.

14. Leversedge FJ, Seiler JG 3rd, Toye-Vego M, Fleming LL. Wrist arthrodesis using a wrist fusion plate. J South Orthop Assoc 1999;8:86-92.

15. Voutilainen NH, Pätiälä HV, Juutilainen TJ, Rokkanen PU. Long-term results of wrist arthrodeses fixed with selfreinforced polylevolactic acid implants in patients with rheumatoid arthritis. Scand J Rheumatol 2001;30:149-53.

16. Zachary SV, Stern PJ. Complications following AO/ASIF wrist arthrodesis. J Hand Surg [Am] 1995;20:339-44.

17. Houshian S, Schrøder HA. Wrist arthrodesis with the AO titanium wrist fusion plate: a consecutive series of 42 cases. J Hand Surg [Br] 2001;26:355-9.

18. Toma CD, Machacek P, Bitzan P, Assadian O, Trieb K, Wanivenhaus A. Fusion of the wrist in rheumatoid arthritis: a clinical and functional evaluation of two surgical techniques. J Bone Joint Surg [Br] 2007;89:1620-6.

19. Abbott LC, Saunders JBDM, Bost FC. Arthrodesis of the wrist with the use of grafts of cancellous bone. J Bone Joint Surg [Am] 1942;24:883-98.

20. Urbaniak JR. Arthrodesis of the hand and wrist: surgery of the musculoskeletel system. In: Evert CM, editor. New York: Churchill Livingstone; 1981.

21. Bolano LE, Green DP. Wrist arthrodesis in post-traumatic arthritis: a comparison of two methods. J Hand Surg Am 1993;18:786-91.

22. Rauhaniemi J, Tiusanen H, Sipola E. Total wrist fusion: a study of 115 patients. J Hand Surg Br 2005;30:217-9. 